\title{
Estimation of herbicide bioconcentration in sugarcane (Saccharum officinarum L.)
}

\author{
Modelagem de bioconcentração de herbicidas em cana (Saccharum officinarum L.)
}

\begin{abstract}
Antonio Luiz Cerdeira ${ }^{\mathrm{I}^{*}}$ Lourival Costa Paraíba ${ }^{\mathrm{I}}$ Sonia Claudia Nascimento de Queiroz Marcus Barifouse Matallo ${ }^{I I}$ Daniel Andrade de siqueira FrancoII Vera Lúcia Ferracini ${ }^{\mathrm{I}}$
\end{abstract}

\section{ABSTRACT}

Sugarcane is an important crop for sugar and biofuel production in Brazil. Growers depend greatly on herbicides to produce it. This experiment used herbicide physical-chemical and sugarcane plant physiological properties to simulate herbicide uptake and estimate the bioconcentration factor (BCF). The $(B C F)$ was calculated for the steady state chemical equilibrium between the plant herbicide concentration and soil solution. Plantwater partition coefficient (sugarcane bagasse-water partition coefficient), herbicide dilution rate, metabolism and dissipation in the soil-plant system, as well as total plant biomass factors were used. In addition, we added Tebuthiuron at rate of $5.0 \mathrm{~kg}$ a.i. $\mathrm{ha}^{-1}$ to physically test the model. In conclusion, the model showed the following ranking of herbicide uptake: sulfentrazone $>$ picloram $>$ tebuthiuron $>$ hexazinone $>$ metribuzin $>$ simazine $>$ ametryn $>$ diuron $>$ clomazone $>$ acetochlor. Furthermore, the highest $B C F$ herbicides showed higher Groundwater Ubiquity Score (GUS) index indicating high leaching potential. We did not find tebuthiuron in plants after three months of herbicide application.

Key words: herbicide, bioconcentration factor, plant uptake, model, bagasse adsorption.

\section{RESUMO}

A cana de açúcar é uma cultura importante para produção de açúcar e biocombustiveis no Brasil e exige elevada utilização de herbicidas. Utilizamos modelo matemático para ajudar na compreensão da absorção de herbicida dessa cultura. Propriedades físico-químicas dos herbicidas e propriedades fisiológicas das plantas de cana foram usados para estimar a absorção e também o fator de bioconcentração, bioconcentration factor $(B C F)$, calculado para o equilibrio químico entre a concentração do herbicida na planta e na solução do solo. $O$ coeficiente de partição plantalágua, a taxa de diluição de herbicida, o metabolismo e a dissipação no sistema solo-planta e biomassa total das plantas foram adicionados ao modelo. O herbicida tebuthiuron aplicado ao solo na dose de 5,0 $\mathrm{kg} \mathrm{ha}^{-1}$ i.a. foi utilizado para testar o modelo. A absorção dos herbicidas mostrada pelo modelo indicou em ordem o seguinte: sulfentrazone $>$ picloram $>$ tebuthiuron $>$ hexazinone $>$ metribuzin $>$ simazina $>$ ametryn $>$ diuron $>$ clomazone $>$ acetochlor. Esses herbicidas com alto indice (BCF) também apresentaram alto indice de potencial de lixiviação para água subterrânea "Groundwater Ubiquity Score" (GUS). Tebuthiuron não foi encontrado nas plantas após três meses de aplicação.

Palavras-chave: herbicida, fator de bioconcentração, absorção, estimativa, adsorção bagaço.

\section{INTRODUCTION}

In Brazil, sugarcane area encompasses more than 5 million hectares. Farmers produce more than 570 million tons of sugarcane yearly. The industry uses this crop to produce sugar, alcohol and other derivates (ALCOPAR, 2012). This production level reflects the sugarcane favorable climate in many parts of Brazil. However, those same environmental conditions also favor the growth of several weed species, and growers use herbicides to manage them.

Sugarcane requires large amounts of water during its vegetative cycle and has a high transpiration rate. Normally water is also the vehicle of herbicide uptake by the plants. The herbicides used in sugarcane cultivation have high water solubility, long soil half-life, and high

IEmbrapa meio Ambiente, Rodovia SP-340, Km 127,5, Tanquinho Velho, CP 69, 13820-000, Jaguariúna, SP, Brasil. E -mail: antonio.cerdeira@embrapa.br. *Corresponding author.

IILaboratório de Plantas Daninhas, Instituto Biológico, Agência Paulista de Tecnologia dos Agronegócios (APTA), Campinas, SP, Brasil. Received 06.29.12 Approved 12.02.13 Returned by the author 11.18.14 CR-2012-0466.R2 
accumulation potential in plants (TRAPP, 1995; COUSINS \& MACKAY, 2001).

Mathematical models predict plant herbicide concentrations (TRAPP, 1995). Several models simulate any substance uptake by plants (TRAPP \& MATTHIES, 1995; FUJISAWA et al., 2002; TRAPP et al., 2003; TRAPP, 2007; PARAIBA \& KATAGUIRI, 2008). Some researchers developed models to simulate specific substance uptake by leaves (TRAPP, 1995), roots and tubers, (TRAPP et al., 2003; PARAIBA \& KATAGUIRI, 2008) or by roots and leaves (FUJISAWA et al., 2002; TRAPP, 2007). However, none of these models estimate the herbicide bioconcentration factor and uptake in sugarcane.

The bioconcentration factor of a substance $(B C F)$ in an organism is a coefficient that describes the increase in concentration of herbicides in the organism in relation to concentration in the medium, estimated by the limit in time in the chemical steady state equilibrium. In case of plants for food, the $B C F$ permits scientists to evaluate the human's daily ingestion of pesticide establishing safe limits for concentration in the medium (PARAIBA \& KATAGUIRI, 2008). This research used this model to estimate sugarcane herbicide absorption from soil solution. This work evaluated the $B C F$ of herbicide in sugarcane through physical and chemical properties of herbicides and physiological characteristics of the crop. We chose tebuthiuron as an indicator because it is commonly used in sugarcane cultivation in Brazil and has high mobility (CERDEIRA et al., 2007).

\section{MATERIALS AND METHODS}

\section{The $B C F$ model}

This paper's estimation of sugarcane herbicide bioconcentration relies on several assumptions: degradation in the soil and its metabolism and dilution in the plant are described by first order kinetic equation; the plant uses the water transpiration stream to uptake the herbicide from the soil solution; soil solution herbicide present in concentrations that are available for plant uptake; and the plant distributes the herbicide throughout itself by transpiration. These assumptions reflect the results of several studies (TRAPP, 2007; REIN et al., 2011; TRAPP \& LEGIND, 2011; TRAPP \& EGGEN, 2013).

We obtained the $B C F$ for the steady state chemical equilibrium, which we estimated using the time limit of the quotient between the plant herbicide and the soil solution herbicide concentration. We calculated the total balance of the herbicide's mass through the following equations:

$\frac{M_{P} d C_{P}}{d t}=Q T S C F_{\text {soil }} C_{W}-\left(k_{E}+k_{G}\right) M_{P} C_{P}-\frac{Q C_{P}}{K_{P W}}$

(TRAPP et al., 2003; PARAIBA, 2007; PARAIBA et al., 2010), where $M_{P}\left(\mathrm{~kg} \mathrm{ha}^{-1}\right)$ is the total plant fresh biomass, $Q\left(\mathrm{~L} \mathrm{day}^{-1} \mathrm{ha}^{-1}\right)$ is the plant transpiration rate, $T_{S C F_{\text {soil }}}$ is the herbicide concentration factor in the transpiration stream in relation to the soil solution, $C_{W}$ $\left(\mathrm{mg} \mathrm{L}^{-1}\right)$ is the soil solution herbicide concentration, $k_{E}\left(\right.$ day $\left.^{-1}\right)$ is the herbicide transformation rate in the plant, $k_{\mathrm{G}}\left(\right.$ day $\left.^{-1}\right)$ is the plant growth rate, $C_{P}(\mathrm{mg}$ $\left.\mathrm{kg}^{-1}\right)$ is the plant herbicide concentration, and $K_{P W}(\mathrm{~L}$ $\left.\mathrm{kg}^{-1}\right)$ is the herbicide plant-water sorption coefficient or herbicide bagasse-water sorption coefficient measured as described in the sorption experiments.

The $T S C F_{\text {soil }}$ was estimated from the herbicide octanol-water partition coefficient using the equation, given by (BURKEN \& SCHNOOR, 1998)

$$
T S C F=0.756 \exp \left[\frac{-\left(\log K_{O W}-2.50\right)^{2}}{2.58}\right]
$$

where $\log K_{O W}$ is the logarithm of herbicide octanol-water partition coefficient and TSCF is the concentration factor of pesticide in the transpiration stream without interference of soil elements. The present paper calculates the $T S C F_{\text {soil }}$ is developed by

$$
T S F C_{\text {soil }}=\frac{\theta T S C F}{\theta+K_{O C} f_{O C} \rho_{s}}
$$

(NICHOLLS, 1984), where $K_{O C}\left(\mathrm{~L} \mathrm{~kg}^{-1}\right)$ is the herbicide sorption coefficient in the soil organic carbon, $f_{O C}\left(\mathrm{~g} \mathrm{~g}^{-1}\right)$ is the soil organic carbon volumetric fraction, $\rho_{S}\left(\mathrm{~kg} \mathrm{~L}^{-1}\right)$ is the total soil density, and $\theta\left(\mathrm{g} \mathrm{g}^{-1}\right)$ is the soil water volumetric content.

The experiment measured the herbicide plant-water partition coefficient $K_{P W}\left(\mathrm{~L} \mathrm{~kg}^{-1}\right)$ as follows (Table 1). Initially, it was determined the sorption coefficient of the herbicides in the bagasse (dry pulp that remains after juice extraction) for the development of the model that describes the mass balance of the herbicide in the soil-plant in sugarcane. We selected the following herbicides to evaluate the $B C F$ : acetochlor, ametryn, clomazone, diuron, hexazinone, metribuzin, picloram, simazine, sulfentrazone and tebuthiuron. For this experiment we first washed and processed the sugarcane cane in a manual mill to separate the juice from the bagasse. We then dried the resulting bagasse in an oven with air circulation at $60^{\circ} \mathrm{C}$ for $72 \mathrm{~h}$. After complete drying, we grounded the residue using a knife mill. Then we 
Table 1 - Partition (sorption) coefficients of herbicides in octanol/water, bagasse-water, and solubility.

\begin{tabular}{llll}
\hline Herbicide & $\log K_{O W \mathrm{a}}$ & $K_{P W \mathrm{~b}}$ & $S_{\mathrm{c}}$ \\
\hline Ametryn & 2.63 & 31.5 & 0.2 \\
clomazone & 2.5 & 42.34 & 1.1 \\
Diuron & 2.85 & 88.14 & 0.0364 \\
hexazinone & 1.2 & 9.4 & 33 \\
metribuzin & 1.6 & 17.7 & 1.05 \\
Simazine & 2.1 & 21.13 & 0.0062 \\
sulfentrazone & 1.48 & 20.2 & 110 \\
tebuthiuron & 1.79 & 13.02 & 2.5 \\
\hline
\end{tabular}

${ }^{\mathrm{a}} \log K_{O W}$ : partition coefficient octanol-water of herbicide $\left(\mathrm{L} \mathrm{kg}^{-1}\right)($ TOMLIN, 2000).

${ }^{\mathrm{b}} K_{P W}$ : partition coefficient bagasse-water of the herbicides (measured).

${ }^{\mathrm{c}}$ Sol: water solubility $\left(\mathrm{g} \mathrm{L}^{-1}\right)$ (TOMLIN, 2000).

washed the bagasse with distilled water and filtered it through qualitative filter paper (Whatman n. 1), using a Büchner funnel. After washing, we again dried the residue under the same conditions described above and sieved in a $1 \mathrm{~mm}$ sieve.

The soil solution herbicide concentration followed a first order kinetic equation given by $C_{W}(t)$ $=C_{W}(0) \exp \left(-k_{S} t\right)$, where $C_{W(0)}\left(\mathrm{mg} \mathrm{L}^{-1}\right), C_{W}=C_{W}(t)$ $\left(\mathrm{mg} \mathrm{L}^{-1}\right)$ and $k_{S}\left(\right.$ day $\left.^{-1}\right)$ are the initial soil solution herbicide concentration, the current soil solution herbicide concentration, and the herbicide dissipation rate in the soil, respectively. The equation

$$
C_{P}(t)=\frac{A C_{W}(0)}{\left(B-k_{S}\right)}\left[\exp \left(-k_{S} t\right)-\exp (-B t)\right]
$$

describes the plant herbicide concentration, where

$$
\begin{aligned}
& A=\frac{Q T S C F_{\text {soil }}}{M_{P}} \quad\left(\mathrm{~L} \mathrm{~kg} \mathrm{day}^{-1} \mathrm{ha}^{-1}\right) \text { and } \\
& B=\left(k_{E}+k_{G}\right)+\frac{Q}{M_{P} K_{P W}}\left(\text { day }^{-1}\right)
\end{aligned}
$$

$\left(\right.$ day $\left.^{-1}\right)$. The $A$ constant is the herbicide uptake rate by plants and the $B$ constant is herbicide dilution and metabolic rate in the plants.

We calculated the bioconcentration factor for the steady state chemical equilibrium by the time limit of the quotient between the plant herbicide and soil solution herbicide concentrations, as follows

$$
B C F=\lim _{t \rightarrow \infty} \frac{\mathrm{C}_{\mathrm{p}}(t)}{C_{W}(t)}=\frac{Q T S C F_{\text {soil }} K_{P W}}{Q+k_{E G S} K_{P W} M_{P}},
$$

where $B C F\left(\mathrm{Lkg}^{-1}\right)$ is the plant herbicide bioconcentration factor and $k_{E G S}=k_{E}+k_{G}-k_{S}\left(\right.$ day $\left.^{-1}\right)$ is the herbicide dilution rate, metabolism and dissipation in the soilplant system (PARAIBA, 2007; PARAIBA et al., 2010).
Previous research provided the herbicide half-life time values and the soil sorption coefficients (HORNSBY et al., 1995). This experiment uses the half-life time to estimate the degradation rate, $k_{s}$ values, through the expression $k_{S}=0.693 / \mathrm{t}_{1 / 2}$, where $t_{1 / 2}$ (day) is the soil herbicide half-life (HORNSBY et al., 1995). Although polar herbicides $K_{o c}$ varies with soil $\mathrm{pH}$ with geographical regions, normally crop soils pHs are adjusted to near 6 worldwide, thus validating the possible use of literature for this estimation (OLIVEIRA et al., 2001).

Sorption kinetics and chromatographic analysis of the herbicides

The equation $C_{P}=K_{P W} C_{W}$ determines the sorption coefficients, where $C_{P}\left(\mu \mathrm{g} \mu \mathrm{g}^{-1}\right)$ is the concentration of the herbicides the bagasse sorbed, $C_{W}\left(\mu \mathrm{g} \mathrm{mL}^{-1}\right)$ is the concentration in water solution, and $K_{P W}$ is the partition coefficient bagasse-water of the herbicides measured. The equation $X / M=K_{P W} C_{f W}$ provides the coefficients, where $X(\mu \mathrm{g})$ is the amount of herbicide sorbed, and $M(\mu \mathrm{g})$ is the weight of bagasse and $C_{f W}\left(\mu \mathrm{g} \mathrm{mL}^{-1}\right)$ is the final concentration of herbicide in solution. The formula $X=\left(C_{i W}-C_{f W}\right) V$ measures the amount of herbicide sorbed, where $C_{i W}$ $\left(\mu \mathrm{g} \mathrm{mL}^{-1}\right)$ is the initial concentration of the herbicide in solution and $V(\mathrm{~mL})$ is the volume of solution (Table 1) (TRAPP et al., 2001).

We performed sorption kinetics and isotherms curves for each individual herbicide. We kept the rate of bagasse:solution at 1:15 (1g bagasse $15 \mathrm{~mL}$ of solution of $1 \mu \mathrm{g} \mathrm{mL}^{-1}$ of herbicide in water), and maintained the samples at a temperature of $25^{\circ} \mathrm{C}$, shaking at $185 \mathrm{rpm}$. To quantify and determine the point on time of equilibrium of herbicide absorbed, took the aliquots and filtered in $0.45 \mu \mathrm{m}$ sieve for 
herbicide at regular intervals. The initial time of the experiment $(t=0)$ was when we applied the herbicide to the media. We performed the analyses on HPLC using a UV-Vis detector (Shimadzu, model SPD 10AVvp), Supelco-Lichosorb RP-18.5 $\mu \mathrm{m}$ (250mm-

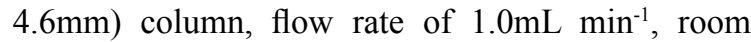
temperature and injection volume of $20 \mu \mathrm{L}$. Each herbicide had a specific chromatographic conditions (mobile phase and UV wavelength). All herbicides reached equilibrium within a period of 24 hours. For construction of the isotherms, seven standard concentrations, ranging from 0.1 to $8.0 \mu \mathrm{g} \mathrm{mL}^{-1}$, in duplicate were used.

\section{Tebuthiuron sugarcane uptake experiment}

To conduct the experiment we used containers of $40 \times 10^{3} \mathrm{~cm}^{3}$ capacity with organic sugarcane so as to avoid interference with other chemicals watered to maintain at field capacity, IAC2480 variety. The experiment was conducted at $\mathrm{pH} 5.9\left(\mathrm{CaCl}_{2}\right)$, soil organic carbon of $0.012 \mathrm{~g} \mathrm{~g}^{-1}$, total soil density of $1.3 \mathrm{~kg} \mathrm{~L}^{-1}$; and soil moisture of $0.28 \mathrm{~g} \mathrm{g.}{ }^{-1}$ The herbicide tebuthiuron was applied at of $5.0 \mathrm{~kg}$ a.i. $\mathrm{ha}^{-1}$, a rate that although higher than the recommended application rate did not cause phytotoxicity to the plant. We used higher rates to simulate a worst case scenario. We harvested the sugarcane every three months after application in order to quantify the herbicide until 20 months old.

\section{RESULTS AND DISCUSSION}

We applied the model to the sugarcane with the following soil and plant parameters: soil organic carbon $=0.012 \mathrm{~g} \mathrm{~g}^{-1}$; total soil density $=1.3 \mathrm{~kg}$ $\mathrm{L}^{-1}$; soil humidity $=0.28 \mathrm{~g} \mathrm{~g}^{-1}$; total plant fresh biomass $=80,000 \mathrm{~kg} \mathrm{ha}^{-1}$; average plant transpiration rate $=$ $32,000 \mathrm{~L} \mathrm{day}{ }^{-1} \mathrm{ha}^{-1}$; and average relative plant growth rate $=0.05$ day $^{-1}$ (CABRAL et al., 2003). The plant herbicide metabolism rate $k_{E}$ was calculated by $k_{E}=$ $k_{S} / 16$ (JURASKE et al., 2008).

The data (Table 1) were used to produce two curves correlation of herbicide properties such as water solubility, partition coefficient octanol-water, and sorption coefficient in bagasse. The equations $\log K_{P W}=0.45+0.46 \times \log K_{O W}$, with $\mathrm{P}<0.001, n=8$, correlation coefficient $R-s=79.75 \%$, standard deviation $=0.15$ (Equation 1) and $\log K_{P W}=$ $0.29+0.046 \times \log S o l+0.54 \times \log K_{O W}$, with $\mathrm{P}<0.001, n$ $=8$, correlation coefficient $R-S=82.93 \%$, standard deviation $=0.155$ (Equation 2), were developed.

Equations 1 and 2 show the relationship of the sorption coefficient plant/water or bagasse/water with the coefficient octanol-water. Due to the high solubility of the herbicides picloram and acetochlor, the analytical method did not work as for the other herbicides. For this reason, we used the equations to estimate sorption coefficient bagasse/water for the herbicides: acetochlor $\left(S o l=0.233 \mathrm{~g} \mathrm{~L}^{-1}\right.$ and $\log K_{O W}$ $=4.14$ ) and picloram $\left(S o l=0.430 \mathrm{~g} \mathrm{~L}^{-1}\right.$ and $\log K_{O W}$ $=19)$. Sorption coefficient bagasse-water $\left(K_{P W}\right)$ of acetochlor was 230 (Equation 1) and 313L kg-1 (Equation 2). Picloram was 21 (Equation 1) and 19L $\mathrm{kg}^{-1}$ (Equation 2). The Pesticide Manual provided the values of $S o l$ (soubility) and $\log K_{O W}$ (octanol-water partition coefficient) of the herbicides (TOMLIN, 2000). The values obtained from Equation 1 for picloram and acetochlor were used to feed the model.

Sugarcane herbicide $B C F$ varied between $0.0081 \mathrm{~L} \mathrm{~kg}^{-1}$ (acetochlor) and $0.8570 \mathrm{~L} \mathrm{~kg}^{-1}$ (sulfentrazone) (Table 2). Based on the $B C F$ values measured (Table 2), we concluded that the herbicides that would most probably be found in plant are sulfentrazone $>$ picloram $>$ tebuthiuron $>$ hexazinone $>$ metribuzin $>$ simazine $>$ ametryn $>$ diuron $>$ clomazone $>$ acetochlor. Herbicides with small $K_{P W}$ and $K_{O C}$ and high $T S C F_{\text {soil }}$ are the ones with the highest $\mathrm{BCF}$, such as sulfentrazone, picloram, tebuthiuron, hexazinone, and metribuzin (Table 2). The herbicides ametryn, diuron, clomazone, and acetochlor have the lowest $B C F$ and have in common high $K_{O C}, K_{O W}, K_{P W}$, and low $T S C F_{\text {soil }}$ (Table 2).

The $B C F$ (Table 2) values permit an estimation of the herbicide daily intake $(D I)$, per body weight, from sugarcane products consumption establishing acceptable limits. For example, a soil solution containing $1.0 \mathrm{mg} \mathrm{L}^{-1}\left(C_{W}\right)$ of tebuthiuron leads to a sugarcane concentration $\left(C_{P}\right)$ of $0.4159 \mathrm{mg}$ $\mathrm{kg}^{-1}\left(C_{P}=\mathrm{BCFx} C_{W}\right)$ and a daily herbicide intake of $0.003 \mathrm{mg} \mathrm{kg}^{-1}$ (mg of tebuthiuron per kg body weight) considering a $70 \mathrm{~kg}$ person with a daily sugarcane juice consumption $(D I)$ of $0.5 \mathrm{~kg}$, measured by $\mathrm{DI}=0.5 \mathrm{X} C_{P} / 70$.

Besides being absorbed, herbicides could leach to groundwater. We can estimate the herbicide leaching potential through the GUS index (GUSTAFSON, 1989), given by $G U S=\left(4-\log K_{O C}\right) \mathrm{x}$ $\log t_{1 / 2}$. Depending on the GUS index numerical value, we may classify the herbicide as a high leaching potential (GUS $\geq 2.8$ ), non-leaching $(G U S \leq 1.8)$ or with undetermined leaching potential (transient) $(1.8<G U S<2,8)$. Therefore, herbicides with low soil sorption coefficients and high water solubility, are classified as leaching pesticides because of their GUS index values (Table 2). High soil herbicide sorption makes them adsorbed in soil matrix, and thus, 
Table 2 - Herbicide physical-chemical characteristics and the bioconcentration factors determined in sugarcane.

\begin{tabular}{|c|c|c|c|c|c|c|c|}
\hline Herbicide & $\log K_{O W}$ & $t^{a}{ }_{1 / 2}$ (day) & $K^{a}{ }_{O C}\left(\mathrm{~L} \mathrm{~kg}^{-1}\right)$ & $K_{P W}\left(\mathrm{~L} \mathrm{~kg}^{-1}\right)$ & $T S C F_{\text {soil }}$ & GUS & $\mathrm{BCF}\left(\mathrm{L} \mathrm{kg}^{-1}\right)$ \\
\hline sulfentrazone & 1.48 & 310 & 23 & 20.20 & 0.2214 & 6.57 & 0.8570 \\
\hline Picloram & 1.9 & 90 & 16 & 21.14 & 0.3476 & 5.46 & 0.7539 \\
\hline Tebuthiuron & 1.79 & 360 & 80 & 13.02 & 0.1139 & 5.36 & 0.4159 \\
\hline Hexazinone & 1.2 & 90 & 54 & 9.40 & 0.0980 & 4.43 & 0.1883 \\
\hline Metribuzin & 1.6 & 40 & 60 & 17.70 & 0.1272 & 3.56 & 0.1530 \\
\hline Simazine & 2.1 & 60 & 130 & 21.13 & 0.0862 & 3.35 & 0.1424 \\
\hline Ametryn & 2.63 & 60 & 300 & 31.50 & 0.0424 & 2.71 & 0.0719 \\
\hline Diuron & 2.85 & 90 & 480 & 88.14 & 0.0260 & 2.58 & 0.0611 \\
\hline clomazone & 2.5 & 24 & 300 & 42.34 & 0.0427 & 2.10 & 0.0347 \\
\hline acetochlor & 4.14 & 13 & 261 & 229.70 & 0.0172 & 1.76 & 0.0081 \\
\hline
\end{tabular}

$\log K_{O W}$. herbicide octanol-water partition coefficient; $K_{O C}$ : herbicide sorption coefficient in the soil organic carbon; $K_{P W}$ plant-water partition coefficient; GUS : Groundwater Ubiquity Score; BCF: sugarcane herbicide bioconcentration factor; TSCF soil: soil-plant transpiration stream concentration factor; ${ }^{2}$ Data from HORNSBY et al., (1995).

unavailable for lixiviation or plant uptake (TRAPP, 1995). Six of the ten studied herbicides $(60 \%)$ are potentially leaching. One $(10 \%)$ is a non-leaching herbicide and others transient (Table 2). Overall herbicides with the highest $B C F$ or potential to be absorbed are also the ones with highest potential to leach to groundwater (Table 2).

Tebuthiuron bioconcentration

We applied Tebuthiuron to the soil at $5.0 \mathrm{~kg}$ a.i. $\mathrm{ha}^{-1}$, a rate higher than the recommended, without causing phytotoxicity to the plant. We harvested the plants every three months after application for herbicide quantification. We were able to measure and detect the herbicide only during the first harvesting date, three months after application, at a level of 0.5 $\mathrm{mg} \mathrm{kg}{ }^{-1}$. Although, in our study, the herbicide had a significant $B C F$ of 0.42 , it also had a high $G U S$ index rating, 5.36, indicating that most likely it would leach or break down (SILVA et al., 2010) before the plant uptakes the herbicide further.

Other authors found tebuthiuron residues in adult sugarcane plants cultivated in soils treated with $2.2 \mathrm{~kg}$. a.i. ha ${ }^{-1}$ (recommended rate) and $11.2 \mathrm{~kg}$ $\mathrm{ha}^{-1}$ with herbicide residue concentrations of 0.074 and $0.026 \mu \mathrm{g} \mathrm{g}^{-1}$, respectively (CAUX et al., 1997). In this same experiment, the authors' found in their sugarcane bagasse, juice and syrup $\left(11.2 \mathrm{~kg} \mathrm{ha}^{-1}\right)$ contained concentrations of $0.063,0.076$ and $0.193 \mu \mathrm{g}$ $\mathrm{g}^{-1}$, respectively. They found no residues in the sugar obtained from these plants. However, researchers detected residues of three tebuthiuron metabolites in grasses and bushes grown in soils of a semiarid region of Arizona, 11 years after herbicide application (JOHNSEN \& MORTON, 1991). We found no other literature regarding experiments on the application of tebuthiuron to sugarcane plants similar to those reported by CAUX et al. (1997) and JOHNSEN \& MORTON (1991).

Another practical information generated by this study is related to herbicide efficacy for weed control, since herbicides with high $K_{P W}$ such as measured in this study (Table 2) can be less efficient for weed control. These herbicides are pre plant soil applied over a straw left by mechanical harvesting of sugarcane, are adsorbed by the straw residues left and therefore failing to reach the weed seeds that should be controlled (CORREIA et al., 2007).

\section{CONCLUSION}

This study presents a model equation to estimate the $B C F$. This equation depends directly on the herbicide concentration factor in the transpiration stream, the transpiration stream volume and the plant-water partition coefficient; and indirectly on transpiration stream volume, herbicide dilution rate, metabolism and dissipation in the soil-plant system, the plant-water partition coefficient and the plant biomass. This model allows identification of herbicides that might potentially bioconcentrate in sugarcane and sugar products. The herbicides with highest $B C F$ that would most probably be found in plant are sulfentrazone $>$ picloram $>$ tebuthiuron $>$ hexazinone $>$ metribuzin $>$ simazine $>$ ametryn $>$ diuron $>$ clomazone $>$ acetochlor. Overall herbicides with the highest $B C F$ or potential to be absorbed are also the ones with highest potential to leach to groundwater.

Ciência Rural, v.45, n.4, abr, 2015. 


\section{ACKNOWLEDGEMENTS}

This work was supported by The State of São Paulo Research Foundation (FAPESP), Brazil.

\section{REFERENCES}

ALCOPAR. Estatísticas: histórico de produção da cana-de-açúcar no Brasil e no Paraná. 2012. Available from: $<$ http://www.alcopar. org.br>. Accessed: Mar. 20, 2012.

BURKEN, J.G.; SCHNOOR, J.L. Predictive relationships for uptake of organic contaminants by hybrid poplar trees. Environmental Science \& Technology, v.32, n.21, p.3379-3385, 1998. Available from: <http://pubs-acs-org.ez103.periodicos. capes.gov.br/doi/abs/10.1021/es9706817>. Accessed: Oct. 3, 2014. DOI: $10.1021 /$ es9706817.

CABRAL, O.M.R. et al. Fluxos turbulentos de calor sensível, vapor de água e $\mathrm{CO}_{2}$ sobre plantação de cana-de-açúcar (Saccharum sp.) em Sertãozinho-SP. Revista Brasileira de Meteorologia, v.18, n.1, p.61-70, 2003.

CAUX, P.Y. et al. Canadian water quality guidelines for tebuthiuron. Environmental Toxicology and Water Quality, v.12, n.1, p.6195, 1997. DOI: 10.1002/(SICI)1098-2256(1997)12:1<61::AIDTOX9>3.0.CO;2-6.

CERDEIRA, A.L. et al. Leaching and half-life of the herbicide tebuthiuron on a recharge area of Guarany aquifer in sugarcane fields in Brazil. Journal of Environmental Science and Health Part B-Pesticides Food Contaminants and Agricultural Wastes, v.42, n.6, p.635-639, 2007. Available from: <http://www.ncbi. nlm.nih.gov/pubmed/17701698>. Accessed: Oct. 3, 2014. DOI: $10.1080 / 03601230701465593$.

CORREIA, N.M. et al. Crop residues aging on soil and their effects on pre-emergence herbicides. Bragantia, v.66, n.1, p.101-110, 2007.

COUSINS, I.T.; MACKAY, D. Strategies for including vegetation compartments in multimedia models. Chemosphere, v.44, n.4, p.643-654, 2001. Available from: <http://www-sciencedirectcom.ez103.periodicos.capes.gov.br/science/article/pii/ S0045653500005142>. Accessed: Oct. 3, 2014. DOI: 10.1016/ S0045-6535(00)00514-2.

FUJISAWA, T. et al. Improved uptake models of nonionized pesticides to foliage and seed of crops. Journal of Agricultural and Food Chemistry, v.50, n.3, p.532-537, 2002. Available from: <http://pubs-acs-org.ez103.periodicos.capes.gov.br/doi/ abs/10.1021/jf010985j>. Accessed: Oct. 3, 2014. DOI: 10.1021/ jf010985j.

GUSTAFSON, D.I. Groundwater ubiquity score - a simple method for assessing pesticide leachability. Environmental Toxicology and Chemistry, v.8, n.4, p.339-357, 1989. Available from: <http:// onlinelibrary.wiley.com/doi/10.1002/etc.5620080411/abstract>. Accessed: Oct. 3, 2014. DOI: 10.1897/1552-8618(1989)8[339:GU SASM]2.0.CO;2.

HORNSBY, A.G. et al. Pesticide properties in the environment. New York: Springer-Verlag, 1995. 277p.

JOHNSEN, T.N.; MORTON, H.L. Long-term Tebuthiuron content of grasses and shrubs on semiarid rangelands. Journal of Range
Management, v.44, n.3, p.249-253, 1991. Available from: $<$ https:// journals.uair.arizona.edu/index.php/jrm/article/view/8598> Accessed: Oct. 3, 2014. DOI: 10.2307/4002952.

JURASKE, R. et al. Estimating half-lives of pesticides in/ on vegetation for use in multimedia fate and exposure models. Chemosphere, v.70, n.10, p.1748-1755, 2008. Available from: $<$ http://www-sciencedirect-com.ez103.periodicos.capes.gov.br/ science/article/pii/S0045653507010843>. Accessed: Oct. 3, 2014. DOI: $10.1016 / \mathrm{j}$.

NICHOLLS, P.H. Physicochemical evaluation: the environment, and expert system for pesticide preregistration assessment. In: BRIGHTON CROP PROTECTION CONFERENCE: PESTS AND DISEASES, 1984, Brighton, UK. Proceedings... Brighton: British Crop Protection Council, 1984. p.1337-1342.

OLIVEIRA, R.S. et al. Sorption and leaching potential of herbicides on Brazilian soils. Weed Research, v.41, n.2, p.97-110, 2001. Available from: <http://onlinelibrary-wiley-com.ez103.periodicos. capes.gov.br/doi/10.1046/j.1365-3180.2001.00219.x/abstract;js essionid=FDF9396E2DDBF647125925011587ABD2.f02t01> Accessed: Oct. 3, 2014. DOI: 10.1046/j.1365-3180.2001.00219.x.

PARAIBA, L.C. Pesticide bioconcentration modelling for fruit trees. Chemosphere, v.66, n.8, p.1468-1475, 2007. Available from: <http://www-sciencedirect-com.ez103.periodicos.capes. gov.br/science/article/pii/S0045653506011878>. Accessed: Oct. 3, 2014. DOI: 10.1016/j.chemosphere.2006.09.017.

PARAIBA, L.C.; KATAGUIRI, K. Model approach for estimating potato pesticide bioconcentration factor. Chemosphere, v.73, n.8, p.1247-1252, 2008. Available from: <http://www-sciencedirectcom.ez103.periodicos.capes.gov.br/science/article/pii/ S0045653508009156>. Accessed: Oct. 3, 2014. DOI: 10.1016/j. chemosphere.2008.07.026.

PARAIBA, L.C. et al. Bioconcentration factor estimates of polycyclic aromatic hydrocarbons in grains of corn plants cultivated in soils treated with sewage sludge. Science of the Total Environment, v.408, n.16, p.3270-3276, 2010. Available from: $<$ http://www-sciencedirect-com.ez103.periodicos.capes.gov.br/ science/article/pii/S0048969710004043>. Accessed: Oct. 3, 2014. DOI: 10.1016/j.scitotenv.2010.04.026.

REIN, A. et al. New concepts for dynamic plant uptake models. Sar and Qsar in Environmental Research, v.22, n.12, p.191-215, 2011. Available from: <http://www.ncbi.nlm. nih.gov/pubmed/21391147>. Accessed: Oct. 3, 2014. DOI: 10.1080/1062936X.2010.548829.

SILVA, M.R.A. et al. Photo-Fenton degradation of the herbicide tebuthiuron under solar irradiation: Iron complexation and initial intermediates. Water Research, v.44, n.12, p.3745-3753, 2010. Available from: <http://www-sciencedirect-com.ez103.periodicos. capes.gov.br/science/article/pii/S0043135410002782>. Accessed: Oct. 3, 2014. DOI: 10.1016/j.watres.2010.04.025.

TOMLIN, C.D.S. The pesticide manual: a world compendium. 12. Farnham, Surray, United Kingdom: British Crop Protection Council and Royal Society of Chemistry, 2000. 1250p.

TRAPP, S. Model for uptake of xenobiotics into plants. In: TRAPP, S.; MCFARLANE, J.C. (Ed.). Plant contamination: modeling and simulation of organic chemical processes. Boca Raton (FL): Lewis Publishers, 1995. p.107-152. 
Fruit Tree model for uptake of organic compounds from soil and air. Sar and Qsar in Environmental Research, v.18, n.3-4, p.367-387, 2007. Available from: <http://www.ncbi.nlm. nih.gov/pubmed/17514576>. Accessed: Oct. 3, 2014. DOI: $10.1080 / 10629360701303693$.

TRAPP, S.; EGGEN, T. Simulation of the plant uptake of organophosphates and other emerging pollutants for greenhouse experiments and field conditions. Environmental Science and Pollution Research, v.20, n.6, p.4018-4029, 2013. Available from: $<$ http://www.ncbi.nlm.nih.gov/pubmed/23212267>. Accessed: Oct. 3, 2014. DOI: 10.1007/s11356-012-1337-7.

TRAPP, S.; LEGIND, C.N. Uptake of organic contaminants from soil into vegetables and fruits. In: (Ed.).

Dealing with contaminated sites: from theory towards practical application, 2011. p.369-408. ISBN 978-90-481-9756-9.
TRAPP, S.; MATTHIES, M. Generic one-compartment model for uptake of organic-chemicals by foliar vegetation. Environmental Science \& Technology, v.29, n.9, p.2333-2338, 1995. Available from: <http://pubs-acs-org.ez103.periodicos.capes.gov.br/doi/ abs/10.1021/es00009a027>. Accessed: Oct. 3, 2014, DOI: $10.1021 / \mathrm{es} 00009 \mathrm{a} 027$.

TRAPP, S. et al. Sorption of lipophilic organic compounds to wood and implications for their environmental fate. Environmental Science \& Technology, v.35, n.8, p.1561-1566, 2001. Available from: $<$ http://pubs-acs-org.ez103.periodicos.capes.gov.br/doi/abs/10.1021/ es000204f>. Accessed: Oct. 3, 2014., DOI: 10.1021/es000204f.

TRAPP, S. et al. Fruit tree model for uptake of organic compounds from soil. Sar and Qsar in Environmental Research, v.14, n.1, p.17-26, 2003. Available from: <http://www.ncbi.nlm. nih.gov/pubmed/17514576>. Accessed: Oct. 3, 2014. DOI: $10.1080 / 10629360701303693$. 